\title{
THE COBALT ENGIMA - SOME OBSERVATIONS AND STRATEGIES FOR OTAGO AND SOUTHLANO
}

\author{
A.K. Metherell
}

Invermay Agricultural Centre, MAFTech, Mosgiel

\begin{abstract}
The role of cobalt $(\mathrm{Co})$ and vitamin $\mathrm{B}_{12}$ in animal nutrition is well understood. but the practical questions of predicting when and where a deficiency is likely, and the most effective preventive strategy, remain unanswered in Southland and Otago. The incidence of Co deficiency in the region has recently increased, particularly where the problem had not previously been recognised

In a long term maintenance Co topdressing experiment at Woodlands Research Station, pasture Co concentrations have been monitored sInce 1982 and lamb growth measured in two seasons.

Cobalt deficiency has been observed only in the two driest seasons. It is postulated that soil manganese may Influence the seasonal availability of Co to pasture plants. The effect of Co topdressing on pasture Co levels in the season of application was very short lived. Rate of cobalt sulphate application affected peak pasture concentration but had little effect on the duration of the pasture response. Lambs grazing treated plots did not gain a substantial reserve of vitamin $B_{12}$ Timing of $C o$ application in relation to the likely period of deficiency is very Important.

Keywords: pasture mineral content, lamb growth rate, vitamin $\mathbf{B}_{1} \mathbf{2}^{\text {, cobalt }}$
\end{abstract}

\section{INTRODUCTION}

The increasing incidence of cobalt (Co) deficiency on farms throughout South Otago and Southland raises the questions: (1) Where and when is Co deficiency likely to occur? (2) What is the most effective strategy for prevention of Co deficiency in livestock?

The function and metabolism of $C_{0}$ in the animal is well understood, and diagnostic tests have been developed, but some practical questions remain. In this paper historical and recent observations are drawn together to shed some light on the Co enigma.

\section{THE HISTORY OF CO DEFICIENCY IN SOUTHLAND AND OTAGO}

The symptoms of Co deficiency in Southland were first described by Dixon (1936). The ailment known loosely as "Morton Mains disease", because it was prevalent in that district, was most serious in lambs during mid-December to the end of January. It did not occur on all farms in the one area and in some years did not occur at all (Andrews 1960). The symptoms generally reflected a state of malnutrition.

Askew \& Dixon (1936) conclusively demonstrated the effectiveness of Co supplements both as a preventive and a cure. The results of Kidson (1937) indicate that low availability rather than a complete lack of Co was important in Southland soils.

Andrews (1970) reports that by 1938 it had become standard farming practice to use Co-enriched fertilisers, usually as commercial cobaltised superphosphate, so as to supply $5 \mathrm{oz}$ cobalt sulphate $\left(\mathrm{CoSO}_{4} .7 \mathrm{H}_{2} \mathrm{O}\right)$ per acre per year $(350 \mathrm{~g} / \mathrm{ha})$. This recommendation was widely followed in Southland until the price of Co fertiliser 
rose from $\$ 2000$ to $\$ 19000$ per $t$ during the late 1970 s. Annual sales of cobalt sulphate by the Southland Co-operative Phosphate Co Ltd dropped from $19 \mathrm{t}$ during the early 1970's to 3 t from 1981 to 1984.

In the early 1980s observations by MAF's Invermay Animal Health Laboratory (J. Gill pers. comm.) indicated that many farmers in the Mataura and Makarewa river basins, traditionally regarded as Co deficient (Andrews 1960), could withhold Co fertiliser for some years without inducing a Co deficiency. However, in the last 6 years there have been many reports of Co deficiency, particularly in areas where the problem had not previously been recognised, including eastern Southland, the Catlins, South Otago downlands and Te Anau districts. As awareness of the problem has increased, so has Co use in the last 4 years, sales in 1988 reaching $25 \mathrm{t}$.

\section{METHODS}

In 1982 a long term maintenance Co topdressing experiment began at Woodlands Research Station on a Waikiwi yellow-brown earth expected to be Co deficient. The site had received regular annual applications of $250 \mathrm{~g} / \mathrm{ha}$ cobalt sulphate for at least 10 years before 1981. Cobalt sulphate was applied as a spray to 0.5 ha plots at rates of $0,60,120$ and $240 \mathrm{~g} / \mathrm{ha}$ in February and November 1982 and annually thereafter. There were 6 replicates in a balanced incomplete block design, each plot being half a paddock Cobalt concentrations have been monitored regularly in unwashed mixed herbage collected from each plot. Data were logarithmically transformed for statistical analysis. In two seasons half of each sample was washed to determine the possible influence of soil contamination on the results.

In the $1986 / 87$ summer a pilot lamb growth trial was run with 4 mobs of lambs (mean liveweight $23 \mathrm{~kg}$ ) "set stocked" on two control and two $240 \mathrm{~g}$ cobalt sulphate/ ha plots from December until April. Half of each mob was injected with $2 \mathrm{mg}$ of vitamin $B,{ }_{2}$ every 4 weeks. Liveweights were measured and blood samples taken for serum vitamin $B_{12}$ analyses. Five lambs initially, 2 from each treatment group at 8 and 16 weeks and 5 per group at the end of the experiment, were slaughtered to obtain liver samples for vitamin $\mathbf{B}_{12}$ analysis. The number of lambs per treatment group was initially 11 , but decreased to 5 during the experiment.

In the $1987 / 88$ summer another lamb growth experiment was run with similar management and measurements to those of the previous year, but with 12 mobs of lambs (mean liveweight $19 \mathrm{~kg}$ ) on 4 plots each of the control, 120 and $240 \mathrm{~g} / \mathrm{ha}$ treatments. Again half were given vitamin $\mathrm{B}_{12}$ injections but only those not injected were slaughtered. Five lambs initially, 2 per group at 4,8 and 12 weeks, and 5 per group at the end of experiment, were slaughtered. The experiment is best described as a split-plot balanced incomplete block design with vitamin $\mathbf{B}_{12}$ injection at the sub-plot level. In both years a strong statistical comparison could be made between the vitamin $B_{12}$ injection treatments, but because of limited replication the comparison between Co topdressing treatments was less precise.

\section{RESULTS}

Each year in the month immediately after cobalt sulphate application pasture Co increased to very high levels. Results for the control and $240 \mathrm{~g} / \mathrm{ha}$ treatments are shown in Fig. 1. Results before September 1982 and for the control in December 1982 and 1983 are omitted because sample contamination is suspected. Pasture Co levels were significantly elevated for only about 6 weeks after cobalt sulphate application. The rate of cobalt sulphate application, from 60 to $240 \mathrm{~g} / \mathrm{ha}$, affected peak pasture levels, but had little effect on the duration of the 
Pasture response. The lowest Co levels in the control treatment have usually been observed in the summer or autumn but there is no consistent monthly pattern. From 1982 to 1988 pasture Co concentrations have fallen only occasionally to marginal (less than $0.1 \mathrm{mg} / \mathrm{kg}$ ) or deficient (less than $0.08 \mathrm{mg} / \mathrm{kg}$ ) ranges, in contrast to observations by the Invermay Animal Health Laboratory of Co deficiency in lambs on many other farms throughout Otago and Southland.

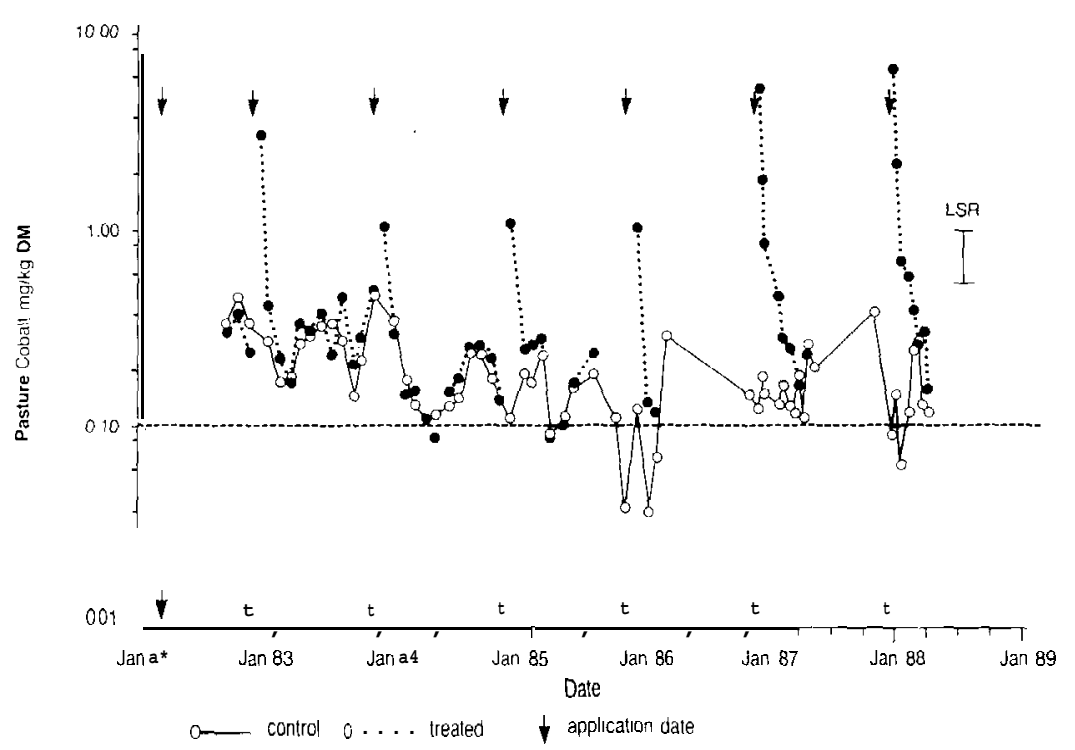

Figure 1: The effect of cobalt sulphate application at $240 \mathrm{~g} / \mathrm{ha} / \mathrm{yr}$ on Co concentrations in mixed pasture. LSR= Least significant Ratio, can be applied to differences on the log scale.

This result probably reflects some residual effect of cumulative Co dressings at Woodlands over many years before 1981, as well as climatic effects. Pasture washing has produced only small differences in Co levels, so it is considered that soil contamination is not seriously biasing the results. In the 1985-86 summer, on the basis of the results obtained, Co topdressing was withheld from the rest of Woodlands Research Station. However low pasture Co levels and Co deficiency in lambs were observed in that season.

In 1986/87 pasture Co levels remained adequate (Fig. 2a) and there were no liveweight gain responses to vitamin $B_{12}$ injection in the lamb growth experiment. An apparent depression in liveweight gain in Co-treated plots was probably caused by differences in pasture quality and thistle growth. In untreated lambs serum vitamin $B_{12}$ fell to marginal levels in February (Fig. 2b) while the liver vitamin $B_{12}$ levels indicated deficiency in January and marginal status in March (Fig. 2C).

Both treatment groups had adequate serum and liver vitamin $B_{12}$ throughout the experiment.

In 1987/88 pasture Co was deficient in control plots in January but was adequate later (Fig. 3a). Both serum and liver vitamin $B_{12}$ started at high levels in December. In untreated animals serum vitamin $B_{12}$ fell to, and remained at, a marginal level from January to April (Fig. 3b). Liver vitamin $B_{12}$ was extremely low in February, with a subsequent increase, but remained marginal until April (Fig. $3 \mathrm{C}$ ). 


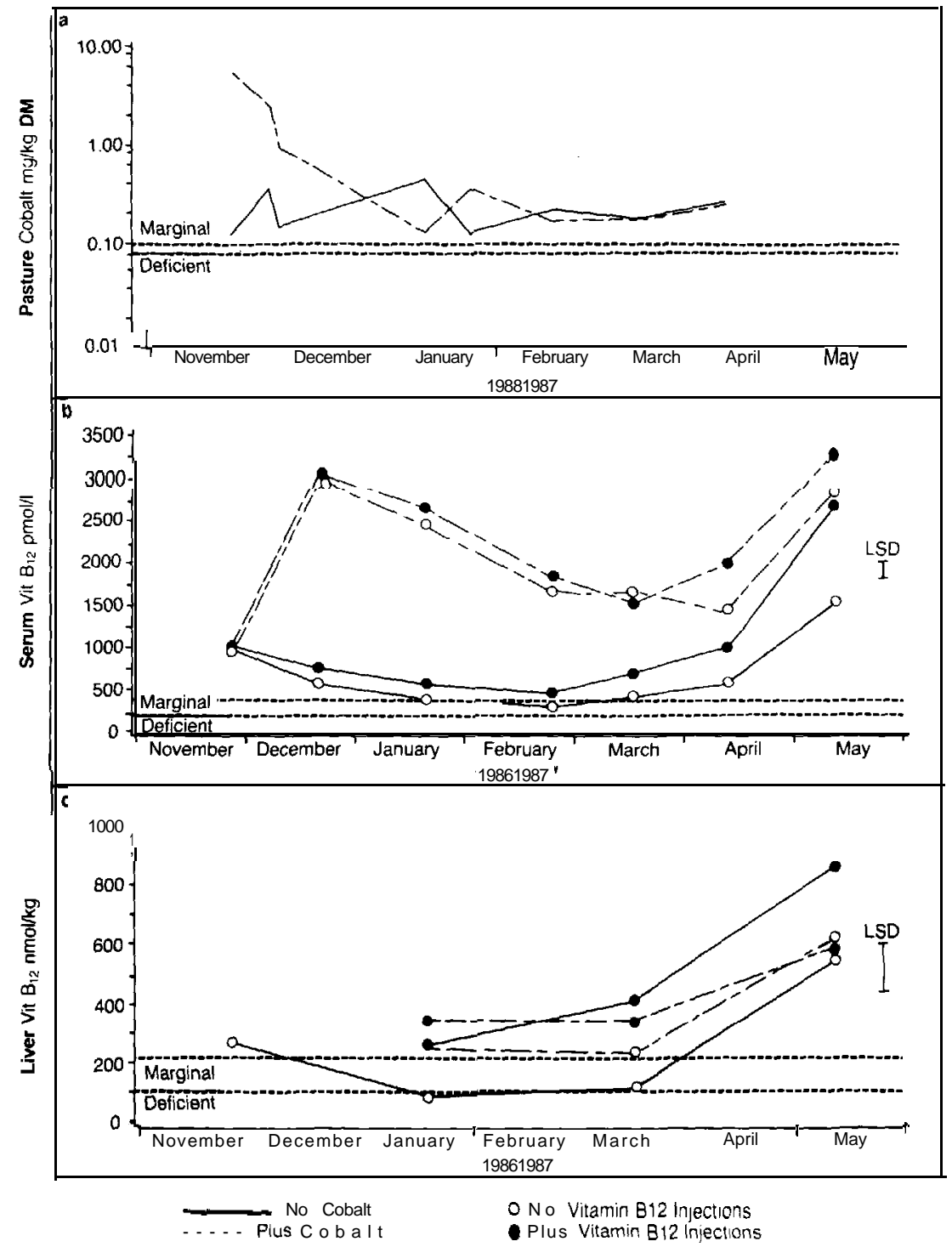

Figure 2: The effect of cobalt sulphate application at $240 \mathrm{~g} /$ ha and monthly vitamin $\mathbf{B}_{1}$ iniections on (a) Co concentration in mixed pasture; (b) serum vitamin $B_{12}$ and (c) liver vitamin $B_{12}$. LSD refers to the effect of vitamin $\mathrm{B}_{12}$ injection within a Co rate.

Cobalt topdressing significantly increased senum vitamin $B_{12}$ to adequate levels from January to April. Liver vitamin $B_{12}$, although significantly above the control, was marginal for both Co rates in February and March. For both senum and liver vitamin $B$, the difference between control and $120 \mathrm{~g} / \mathrm{ha}$ treatments was much larger than the difference between 120 and $240 \mathrm{~g} / \mathrm{ha}$. Again, vitamin $\mathrm{B}_{12}$ injection alone had a small effect on senum vitamin $B_{12}$ measured 4 weeks after the previous 

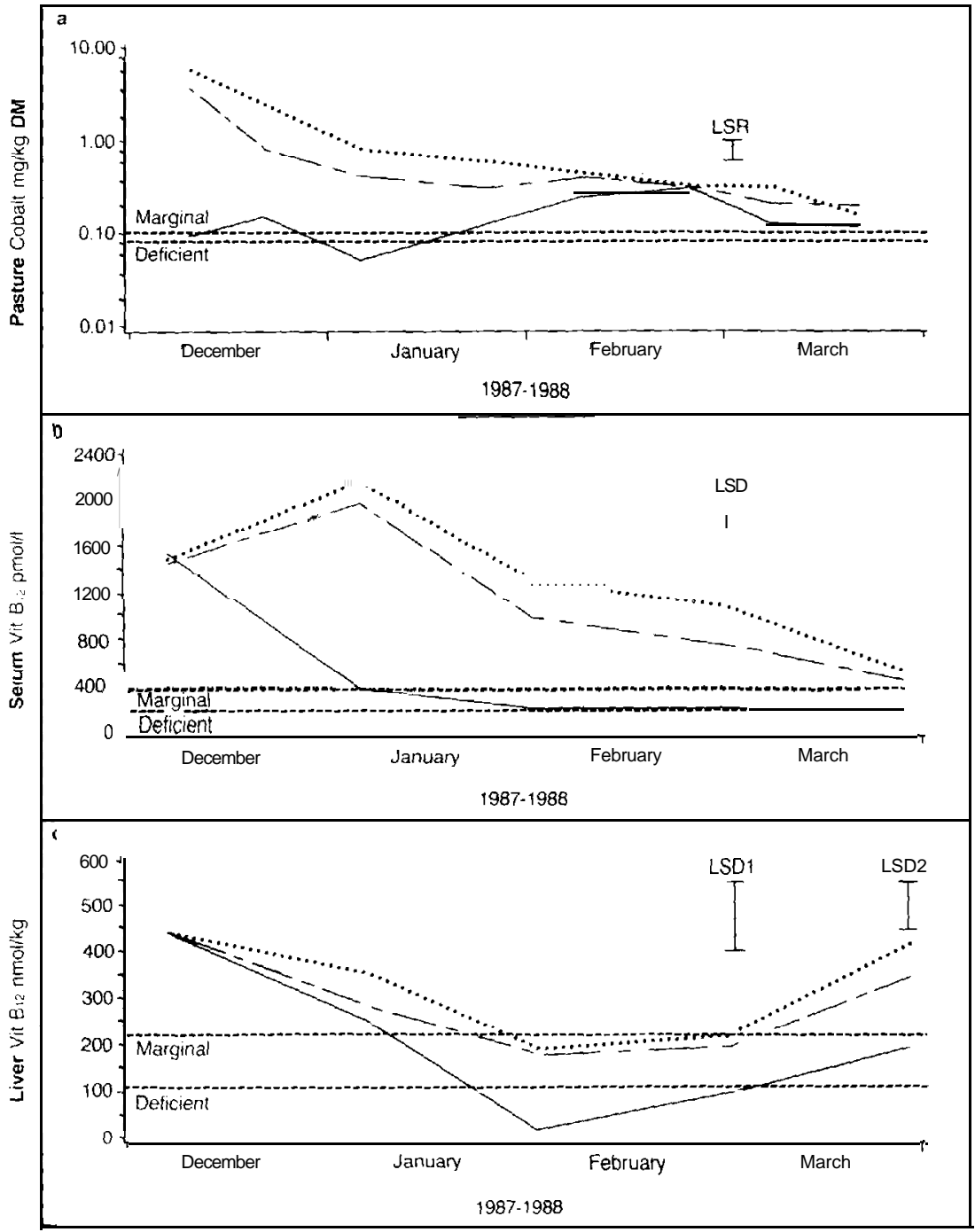

\section{-................. $120 \mathrm{~g}$ cobalt suiphate/ha}

Figure 3: The effect of cobalt sulphate application at 0,120 and $240 \mathrm{~g} / \mathrm{ha}$ on (a) Co concentration in mixed pasture, LSR = Least Significant Ratio, can be applied to differences on the log scale; (b) serum vitamin $B_{12}$ and(c) liver vitamin $B_{12}$ LSD1 refers to earlier samples. LSD2 refers to last sample.

injection (results not shown). In January and February serum vitamin $\mathbf{B}_{12}$ levels from this treatment were marginal.

During January 1988 there was a significant response in liveweight gain to vitamin $\mathbf{B}_{12}$ injection in the lambs grazing control plots (1109 $\vee 143 \mathrm{~g} /$ day; SED 9.8). The effect ${ }^{2}$ was not significant in any other month, but was reflected in DecemberMarch liveweight gain, indicating a lack of compensatory growth. 


\section{DISCUSSION}

The marked annual and seasonal fluctuations in herbage Co levels in control plots suggest a climatic influence on $\mathrm{Co}_{0}$ availability. Comparison of $\mathrm{Co}_{\mathrm{s}}$ levels with meterological data suggests a close association with soil moisture. Using rainfall minus pan evaporation as an index of soil moisture (Fig. 4) Co levels were lowest in the driest months. This conclusion is in direct contrast to earlier observations that Co deficiency is associated with lush spring growth (Gardiner 1977; Clark \& Millar 1983). But our conclusion is plausible because of the association 'between manganese (Mn) and $\mathrm{Co}_{0}$ in the soil (Taylor 8 McKenzie 1966; Childs 1975) and the effect of soil moisture on $\mathrm{Co}$ and $\mathrm{Mn}$ availability (Adams \& Honeysett 1964). A high proportion of the Co in the soil is bound to manganese dioxide $\mathrm{MnO}_{2}$ in $\mathrm{Mn}$ concretions. In wet soils the $\mathrm{MnO}_{2}$ is reduced to the soluble $\mathrm{Mn}^{2+}$ and this probably increases Co availability. Conversely in dry soils the equilibrium will swing towards the insoluble $\mathrm{MnO}_{2}$ and $\mathrm{Co}$ is "locked up". Some support for this hypothesis can be obtained from Mclntosh et al. (1986) who reported that soil drainage appeared to affect the differences between soil types, the drier soils having lower Co availability.

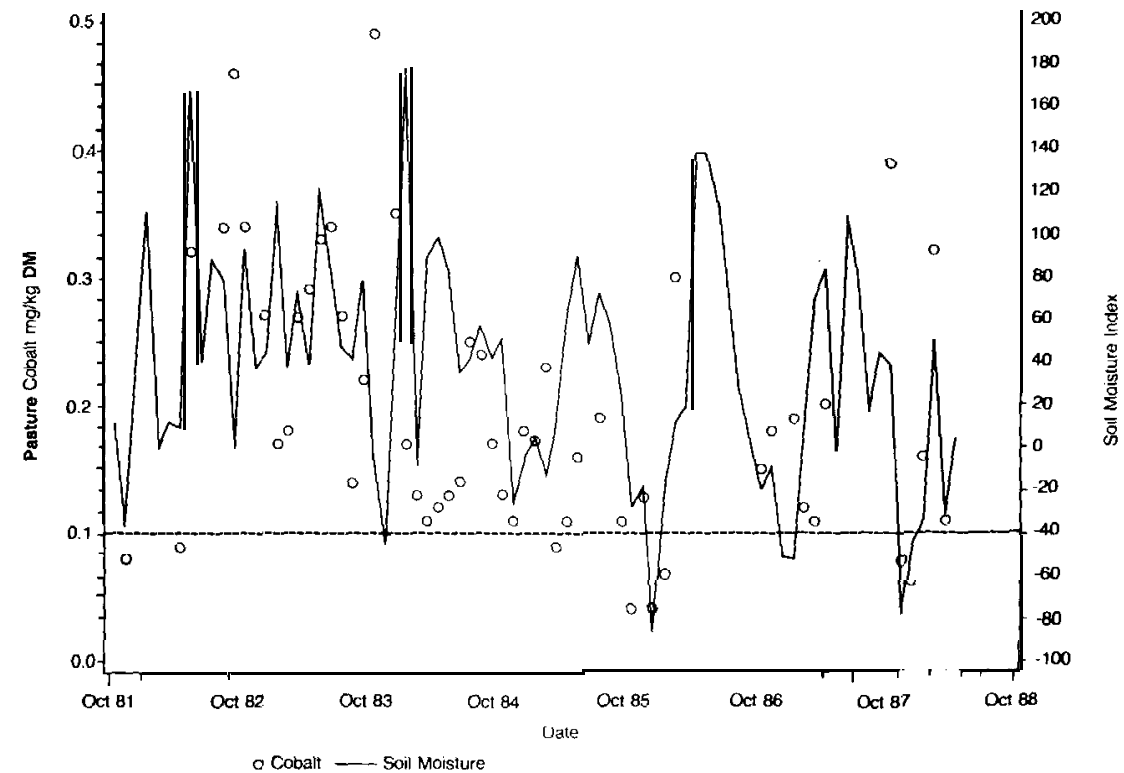

Figure 4: co concentation in mixed pasture in relation to soil moisture status

The rapid decline in pasture Co levels after Co application is also in accordance with an effect of $\mathrm{Mn}$ on $\mathrm{Co}$ availability. Australian researchers (Adams et al. 1969) have found that in soils with more than $1000 \mathrm{mg} / \mathrm{kg}$ air dry soil $\mathrm{Mn}$, Co topdressing in ineffective for preventing $C_{0}$ deficiency in livestock. The level of total $\mathrm{Mn}, 556 \mathrm{mg} /$ $\mathrm{kg}$ air dry soil (SEM 25) was more moderate at Woodlands.

The results must be considered with a little caution because of the infrequent occurrence of deficient pasture analyses; the small effect of treatments on lamb liveweight gain; and the fact that a liveweight gain response was obtained for only one month in 1988. 
Both $120 \mathrm{~g} / \mathrm{ha}$ and $240 \mathrm{~g} / \mathrm{ha}$ prevented Co deficiency in lambs and maintained adequate serum vitamin $B_{12}$ for at least 4 months. However, liver vitamin $B_{12}$ was not maintained above marginal status and the two rates of Co application differed little. In the control treatment liver vitamin $B_{12}$ rapidly declined to a very low level. These results suggest that the liver did not provide a substantial reserve against vitamin $\mathrm{B}_{12}$ deficiency. Hence on a more deficient site or season with a prolonged period of Co deficiency, a single spring application may not be sufficient to prevent Co deficiency in the stock in the autumn. However, this tentative conclusion is in contrast to the statement by Andrews (1960), who in summarising results from experiments on Otapiri soils on the Winton Experimental Farm, in central Southland, concluded that "prior grazing of cobalt-topdressed pastures for three months protects lambs transferred to cobalt deficient land for at least a further four months."

Clearly timing of Co applications in relation to the likely period of deficiency is the most important aspect in the prevention of Co deficiency. The current recommendation is to apply in late spring/early summer, $175 \mathrm{~g} / \mathrm{ha}$ of cobalt sulphate to the paddocks which lambs will be grazing after weaning. However, some farmers, veterinarians and Sherrell et al. (1987) suggest that lambs may be Co deficient before weaning. Hepatic vitamin $B_{12}$ stores are small in the new born lamb (Grace et a/. 1986) and lamb growth and vitamin $B_{12}$ status are influenced by the Co nutrition of the ewe (Quirk \& Norton 1987). On these farms two applications are likely to be most effective.

Liver vitamin $\mathrm{B}_{2}$, is usually the most reliable indicator of Co deficiency, followed by serum vitamin $B_{12}$, with pasture analysis being useful only if monitored regularly. However, the results for the $1987 / 88$ season show that the vitamin $\mathbf{B}_{12}$ levels in both liver and serum lagged behind the pasture Co deficiency and the lamb growth response. In other words liver and serum vitamin $B_{12}$ was useful in explaining what is happening, but not so useful in predicting what is likely to happen.

The Co enigma remains. Co deficiency is still difficult to predict. Diagnostic tests need to be interpreted in relation to the likelihood of Co deficiency developing over the next few months. Monitoring trends in soil moisture status may give some help and is an appropriate direction for future research. Cobalt topdressing is cheap compared with the economic loss associated with reduced lamb growth rates from Co deficiency and the cost of other farm inputs such as phosphate fertilser. Farmers are advised to diagnose correctly the cause of poor lamb growth by response trials to $C o$ or vitamin $B_{12}$ supplementation or the analysis of livers or serum for vitamin $B_{12}$. If a Co deficiency is found pastures should be topdressed strategically with cobalt sulphate.

\section{Acknowledgements}

M. Hishon. K Knowler, C. Mathieson, K Mitchell. K Strachan for technical assistance; B. Hananeia K Turner, J. Fooks and J. Clark for pasture, soil and vitamin $\mathrm{B}_{12}$ analaysis.

\section{References}

Adams. S.N.; Honeysett. J.L. 1964. Some effects of waterlogging on the cobalt and copper status of pasture plants in pots. Australian journal of agricultural research 15: 357-67.

Adams, S.N.; Honeysett, J.L.; Tiller, KG.: Norrish, K 1969. Factors controlling the increase of cobalt in plants following the addition of a cobalt fertiliser. Australian journal of soil research 7: 29-42.

Andrews, E.D. 1960. Trace elements in relation to animal health in Southland. Proceedings NZ Grassland Association 27: $75-83$

Andrew, E.D. 1960. Cobalt and animal health in New Zealand. NZ Agricultural Science July: 6-8; September: 11 . 15.

Askew. H.O.; Dixon JK 1936. The importance of cobalt in the treatment of certain stock ailments in the South Island. New Zealand. NZ journal of SClence and technology 18: 73-92. 
Childs, C.W. 1975. Composition in won-manganese concretions from some New Zealand soils. Geoderma 13: 141-52.

Clark. R.G.; Millar, KR. 1983. Cobalt. In Grace, N.D. (Ed) The mineral requirements of grazing ruminants. NZ Society of Animal Production Occasional Publication No. 9.

Dixon, J.K 1936. Investigations on a sheep ailment in Southland. NZ journal of science and technology 17: 60019.

Gardiner, M.R. 1977. Cobalt in ruminant nutrition: a review. Technical Bulletin No. 36. Department of Agriculture of Western Australia.

Grace, N.D.; Clark, R.G.; Mortleman, L. 1986. Hepatic storage of vitamin $B_{12}$ by the pregnant ewe and the foetus during the third trimester. NZ journal of agricultural research 29: 231-32.

Kidson, E.B. 1937. Cobalt status of New Zealand soils. NZ journal of science and technology 18: 694-707.

McIntosh, P.D., Sherrell, C.G.; Prema G. 1986. Distribution of cobalt, copper and zinc in upland and lowland soils of the Kaiwera District, Eastern Southland. New Zealand. NZ Soil Bureau Scientific Report 78: $19 \mathrm{p}$.

Quirk, M.F.: Norton, B.W. 1987. The relationship between the cobalt nutrition of ewes and the vitamin $\mathbf{B}_{1}{ }_{2}$ status of ewes and their lambs. Australian Journal of Agricultural Research 38: 107 I-82.

Sherrell, C.G.; Brunsden, P.; Mclntosh P.D. 1987. Pasture cobalt concentration and its effect on vitamin B, status of sheep grazing upland and lowland pastures in the Kaiwera district, eastern Southland, New Zealand. NZ journal of agricultural research 30: 325-31.

Taylor, A.M.; McKenzie. R.M. 1966. The association of trace elements with manganese minerals in Australian soils. Australian journal of soil research 4: $29-39$ 